\title{
A New Future for the World Federalist Movement?
}

Fernando Iglesias

From the $9^{\text {th }}$ to the $13^{\text {th }}$ of July, 2018, the World Federalist Movement held its Congress in The Hague. It was the $27^{\text {th }}$ Congress since the WFM's creation, which took place in Montreux, Switzerland, immediately after the Second World War. On this opportunity, last month 37 delegates from 16 countries arrived to The Netherlands to discuss the global political situation and the reform of the movement's rules and governing bodies. The Congress also aimed at finding the best strategies to defend the basic aims that the WFM has promoted since its creation: World Peace through World Law, as the flag over the heads of Montreux delegates showed as early as 1947.

INTERNAL REFORM - This Congress was most certainly not business-as-usual. The internal reform that the WFM members have been discussing for over a decade was on the table, and a series of concrete proposals delivered by a Tasking Group created with this aim by the council were debated, and a grand majority of them, approved. Hence, the WFM has changed its three-body structure (the Congress, the Council and the Executive Committee) into a simplified structure of two bodies, a Legislative Assembly (the Congress) and an Executive body (the Executive Committee). Another important decision radically changed the frequency of the WFM meetings and their powers by establishing that the Congress must meet every two years (instead of every 4 to 6 years) and that it is now vested with complete authority to change statutes, strategies and officials. In short, the changes lead to simplification and dynamism. This is the change that the Movement discussed during years, and it will allow a better execution of the WFM strategies by adapting its structures to a fast-changing global scenario.

\section{INSTITUTIONAL-BUILDING STRATEGY}

- Among the many crucial issues that were discussed during the week, the Congress passed a resolution promoted by Democracia Global in order to better fix the WFM's strategy. Following the original Declaration of Montreal (1947) and current statutes, the $27^{\text {th }}$ Congress concluded and stated that institutional building is the WFM's concrete goal, and that this must be better reflected in our activities during the coming years. The Congress also defined four basic campaigns to be funded and empowered as part of the movement's activities:

1) the campaign to expand and empower the International Criminal Court by means of the Coalition for the ICC;

2) the defense of the European integration process and the deepening of the democratization of the European Union through a close collaboration with EU federalist organizations such as the Union of European Federalists and the European Movement;

3) the support of the campaign in favor of the creation of a United Nations Parliamentary Assembly , one of the most important federalist initiatives that was developed during the past 10 years by a small group of organizations, which has recently gained the support of the European Parliament;

4) the creation of a Latin American and Caribbean Criminal Court Against 
Transnational Organized Crime (COPLA); a project that was promoted by Democracia Global-Buenos Aires that is gaining increasing consensus among civil societies and political groups in all Latin-America.

The COPLA campaign has already gained the support of both houses of the Argentine Congress, the Parliament of the Mercosur, the EUROLAT (the Assembly of European and Latin American Regional Parliaments) and prestigious figures such as Mario Vargas Llosa, David Held, Anthony Giddens among others, have stated their support for the campaign. The campaign was also recently undertaken by the Argentine national government as a state policy and the Ministers of Justice, Security and Internal Affairs of the Mercosur have passed a resolution considering its creation as the most appropriate strategy to fight against the scourge of organized crime in the region.

\section{TRANSNATIONAL WORKING GROUPS -}

The creation of Transnational Working Groups (TWG) oriented towards promoting federalist strategies for the resolution of emerging global issues was another important reform passed by the Congress. Different areas of interest and expertise were identified and consequentially, five transnational working groups were created: 1 - Climate Change and Ecology; 2- Financial Regulation and Global Economy; 3- Peace, Nuclear disarmament and Terrorism; 4- Migrants' and Minorities' Rights; and 5- Regulation of Artificial Intelligence and Disruptive Technologies. These five groups are aimed at promoting concrete federalist proposals among the many global NGOs that work on these fields but lack any federalist approach.Tothisend, the Transnational Working Groups will connect to the members of the World Federalist Movement who live in distant parts of the world using digital technology.

By analyzing the situation in their respective fields and discussing the most appropriate strategies, these new TWGs should be able to promote a federal approach to solutions for many emerging issues which the future of human-kind depends on. Much like how the WFM helped Amnesty International, Human Rights Watch, No Peace without Justice and other international organizations that were active in the field of International Justice and Human Rights to promote the creation of the International Criminal Court. Meaningfully, these transnational working groups (TWGs) are not only limited to the participation of WFM members. Their participants may be all the individuals who are concerned about the increasing dangers of the global crisis and want global institutions to deliver global solutions in order to regulate and solve them.

AUTHORITIES - Lastly, the Congress elected new authorities for the coming four years: Lloyd Axworthy, Canada's former Minister of Foreign Affairs (1996-2000) and the President of the University of Winnipeg, was confirmed as the co-president of the WFM for the North hemisphere, and I was elected as the copresident for the South hemisphere. In addition, Fergus Watt (WFM Canada) and Florencia Gor (Democracia Global and WFM Canada) were elected as Chairs of the Executive Committee and the Congress, respectively. A whole new Executive Committee was also elected, which stands out for being better gender-balanced, as well as more plural and younger than the previous one.

\section{A NEW FUTURE FOR THE WORLD} FEDERALIST MOVEMENT - Hopefully, the $27^{\text {th }}$ Congress will mark the beginning of a new period for the World Federalist Movement. A new period that will empower its best traditions in order to face the challenges imposed by the techno-economic globalization, the rise of populism and nationalism, and the many emerging global issues which the future of humanity depends on. The combination of 
the internal reform, the definition of new strategies, the creation of Transnational Working Groups and the renewal of authorities allows us to be optimistic about the future. As President, I hope that our new structure will give way to the diversification of strategies and an expansion to South and East by means of specific campaigns.

Nobody ignores that the principles of international rule of law, world federalism and global democracy are no longer prospering within the existing global scenario. However, it is also getting clear for millions and millions of citizens of the world that international rule of law, world federalism and global democracy are needed now more than ever before in human history. Whichever the case may be, the political unity of the world no longer seems as unrealistic or utopian now as it seemed during the process of European integration led by Germany and France at the end of two world wars; and the direction that History took from then on is perfectly known to us all. Therefore, we hope that the crucial contributions that federalists have made to the creation and empowerment of the European Union and the International Criminal Court in the past will be followed by similar successes in the future. The World Federalist Movement has changed itself in order to do so, and the future of the world, as always, is open. 